\title{
Who Are Better Informed Before Analysts' Forecast Changes?
}

\author{
Tae-Jun Park, Sujin Yi, and Kyojik "Roy" Song" \\ Business School, Sungkyunkwan University, Korea
}

\begin{abstract}
Using Korean data, we investigate information asymmetry among investors before analysts change their stock recommendations. By comparing trading activities between individuals, institutions, and foreign investors, we find that there is information asymmetry before analysts change their recommendations. Institutional investors buy/sell the stock before recommendation upgrades/downgrades, but individuals and foreign investors do not anticipate the upcoming news. We also document that the trade imbalance of institutional investors are associated with stock returns upon the announcements of recommendation changes. This result indicates that institutions take advantage of their superior information around the recommendation changes.
\end{abstract}

\begin{abstract}
Abstrak: Dengan menggunakan data di pusat saham Korea, kami menyelidiki asimetri informasi diantara para investor sebelum analis mengubah rekomendasi saham mereka. Dengan membandingkan aktivitas perdagangan yang dilakukan oleh masing-masing individu, lembaga, dan para investor asing, kami menemukan bahwa ada asimetri informasi sebelum analis mengubah rekomendasi mereka. Hal ini terbukti karena para investor dari institusi secara cepat-cepat membeli / menjual saham mereka sebelum adanya rekomendasi kenaikan/ penurunan peringkat, namun sayang sekali hal ini tidak dilakukan oleh investor individu dan investor asing karena mereka tidak mengantisipasi berita yang akan datang. Kami juga menemukan bahwa ketidakseimbangan perdagangan investor institusi terkait dengan pengembalian saham setelah pengumuman perubahan rekomendasi. Penelitian ini menunjukkan bahwa investor institusi dengan sengaja mengambil keuntungan dari informasi yang mereka peroleh tentang perubahan rekomendasi.
\end{abstract}

Keywords: information asymmetry; institutional investor; stock recommendation; trade imbalance

JEL classification: G10; G30

* Corresponding author's e-mail: roysong@skku.edu 


\section{Introduction}

Investors usually utilize earnings forecasts, price forecasts, and stock recommendations of sell-side analysts to make their investment decisions. The investors expect that analysts provide objective, unbiased, and accurate equity research reports to the best of their knowledge. However, the literature has accumulated evidence that sell-side analysts' forecasts are tainted and not objective. ${ }^{1}$ Sell-side analysts working for an investment bank are under pressure to provide optimistic recommendations on firms that can provide business to the investment bank. Analysts working in brokerage houses are also under pressure to provide optimistic recommendations to attract trading revenues because upgrades attract more business than downgrades due to the restrictions on short selling. ${ }^{2}$ To be consistent with these conflicts of interest, previous literature finds that analysts affiliated with investment banks and brokers produce more optimistic earnings, and are more likely to give buy recommendations [for instance, Dugar and Nathan(1995); Michaely and Womack (1999); Cowen et al. (2006); Agrawal and Chen (2008)].

Recently, Irvine et al. (2007) test the "tipping hypothesis" using the data of initial recommendations, and document that brokerage firms provide the contents of affiliated analyst reports to important clients who generate large trading commissions before the information becomes public. Although tipping only benefits some investors, it is not prohibited by regulations in most countries. If some investors have access to the contents of upcoming analysts' reports in advance, then they could exploit their superior information obtained from the reports. In this research, we try to investigate whether information asymmetry gets larger among investors before sell-side analysts change their recommendations.

We use Korean data since the Korea Exchange provides daily trading volume by investor types for all stocks traded on the Korea Stock Exchange (KSE) and the Korea Securities Dealers Automated Quotation (KOSDAQ). We divide investors into three groups, individuals, institutions, and foreigners. Unlike individual investors, institutions frequently communicate with brokerage firms, investment banks, and asset management firms to acquire information, which makes it possible for them to have access to analysts' reports in advance. Also, institutions can interpret and process information more precisely, compared to individuals. Therefore, we conjecture that institutional investors are better informed than individuals on upcoming recommendation changes made by sellside analysts. We also investigate whether foreigners have an informational advantage compared to domestic investors on the recommendation changes. Previous literature provides inconclusive evidence that foreigners perform better than domestic investors in trading stocks. For instance, Grinblatt and Keloharju (2000) find that foreign investors act like momentum investors, with high levels of sophistication, and that they outperform local individual investors in the Finnish stock market. In contrast, Choe et al. (2005) find no evidence that foreign investors are better performed than domestic institutions in the Korean market. Using the

\footnotetext{
${ }^{1}$ Mehran and Stulz (2007) provide an excellent summary of the literature.

${ }^{2}$ In the US the Security and Exchange Commission makes these conflicts of interests available to investors at http://www.sec.gov/investor/pubs/analysts.htm.
} 
Korean data, we compare the activities of informed trading by foreign versus domestic investors around a specific event, an analyst's recommendation change.

To test who has informational advantage among individuals, domestic institutions, and foreign investors, we investigate the buying and selling volume by each investor group around analysts' recommendation changes. For the test, we estimate the standardized trade imbalance (STI, our proxy for buying or selling volume) by each investor group before recommendation changes. The positive (negative) STI indicates the net buying/ selling volume by investors. To test the information asymmetry among the investor groups, we examine whether there is a difference in the STIs by investor groups prior to analysts' recommendation changes and whether the STIs are associated with stock returns upon the announcements of the recommendation changes.

Our sample consists of 1,281 analysts' recommendation upgrades and 1,584 downgrades over the period of 2001-2008. First, we find that there is no significant difference in firm characteristics between the upgrade and downgrade samples. We then examine abnormal returns around the recommendation changes. We find that stock prices start increasing even before the announcements of upgrades, while stock prices begin decreasing after the announcements of downgrades. The mean CAR (cumulative abnormal return) over the window of days -5 to -1 before upgrades is 1.21 percent while that before downgrades is 0.29 percent. The result indicates that capital markets anticipate the positive news, but do not anticipate the negative news. The mean CAR over the window of days 0 to 5 after upgrades is 1.77 percent while that after downgrades is -1.25 percent.
The abnormal returns after recommendation changes are significantly different from zero.

Next, we examine the difference in the STIs by individuals, domestic institutions, and foreigners to test information asymmetry among the investor types. Over the period of days -5 to -1 , the STIs by domestic institutions are 0.36 before upgrades and 0.28 before downgrades, and the STIs are statistically different from zero. The STIs by individuals and foreigners before recommendation changes are not statistically different from zero. The result indicates that domestic institutions buy the stock before the recommendation upgrades and sell before the downgrades. However, individual and foreign investors do not trade anticipating the recommendation changes. Further, we test whether the STIs for each investor type before recommendation changes are associated with abnormal returns upon the announcements of the changes in multivariate regressions after controlling for other determinants. We find that the STI for institutions is positively associated with the CAR and STIs for individuals and foreigners are not associated with the CARs. The result corroborates that domestic institutions trade stocks anticipating analysts' recommendation upgrades or downgrades.

Our paper adds to extant literature by examining the short-term informational advantage of institutions over other investors around analysts' recommendation changes using high-frequency data in Korea. Our evidence shows that domestic institutions take advantage of their superior information around recommendation changes, which is indirectly consistent with Irvine et al.'s (2007) finding. We also contribute to the growing literature on foreign investors' trading in the emerging markets. We find that foreign insti- 
tutions' trading is not distinctive around recommendation changes and does not predict stock returns. This shows that foreign institutions have an informational disadvantage compared to local institutions around the specific event. The result is broadly consistent with Brennan and Cao's (1997) argument that foreign investors experience an informational disadvantage in the local markets.

The rest of the paper is organized as follows. Section II reviews the related literature. Section III describes the data and Section IV explains the empirical findings. Section $\mathrm{V}$ concludes the paper.

\section{Literature Review}

\section{The Information Contents of Analyst Recommendations}

An analyst's report, which contains his (or her) view on whether to buy or sell particular stocks for clients, usually include earnings forecasts, target prices, long-term growth forecasts, and (or) stock recommendations. In general, analysts' stock recommendations fall into one of five categories: strong buy, buy, hold, sell, and strong sell. Analysts revise their recommendations by upgrading or downgrading them when needed. The recommendation changes are commonly regarded as useful information in the market and lead to movements in stock prices.

Where a recommendation about a particular stock is disseminated through various publications and other media outlets, it has an immediate impact on the stock price and trading volume. Many researchers in finance and accounting have investigated whether the "informativeness" of analyst recommendations actually exists. Prior literature shows that analyst recommendations are generally informative. For example, Stickel (1995) and Womack (1996) find a positive stock price reaction to recommendation upgrades and a negative price reaction to downgrades. These studies suggest larger market reactions to recommendation downgrades. Womack (1996), in particular, shows that changes in analysts' recommendations have a meaningful stockprice impact, and this impact exists not only on the date which an analyst revises his or her recommendation but lasts up to several months after the change. Analysts tend to acquire public and private information, process the information, and then incorporate their views into their recommendations. Francis and Soffer (1997) suggest that earnings forecast revisions are accompanied by changes in stock recommendations, and investors impose large weights on the revisions accompanied by buy, hold, or sell recommendations. Ivkovic and Jegadeesh (2004) argue that recommendation upgrades and earnings forecast revisions right before the announcement of an earnings report have more information than those released right after the earnings announcement. Jegadeesh et al. (2004) find that analyst recommendations have a predictive ability in the American stock market and that recommendation changes have a larger predictive ability than recommendation levels. Asquith et al. (2005) examine the reaction of the stock market to all the elements of analysts' reports, such as recommendations, earnings forecasts, target prices, and the revisions of these things, and find that other elements of analysts' reports influence recommendation changes and have significant and positive effects on the return variation around the release of the reports.

Furthermore, investors perceive reports written by analysts, who are important information providers in the market, as being essential to avoid losses as much as possible, 
stemming from their own lack of information about companies and information asymmetry. That is, institutional and individual investors use analysts' reports to make their investment decisions since stock recommendations and recommendation changes are important sources of information for them. According to Brown et al. (2009), mutual funds actively use information about recommendation changes when making decisions on portfolio investments. Boni and Womack (2006) argue that analysts' recommendation changes often lead to profitable trading strategies within industries rather than across the industries. Chen and Cheng (2006) find that institutional investors profit from transactions relying on such recommendations. Mikhail et al. (2007) argue that larger investors' transactions are similar to small investors' in relation to recommendation changes, but stock trading by larger investors depends on the amount of information about recommendation changes while transactions by small investors tend to be concentrated around the time of recommendation changes. In particular, Green (2006) finds that the clients of brokerage firms can make profitable transactions if they have information about analysts' recommendation changes in advance.

\section{Incentives to Pre-Release Analyst Reports to Selective Investors}

Recently, it has been claimed that brokerage firms have incentives to provide the contents of affiliated analysts' reports with important clients in advance who generate large trading commissions for the firms. This is the so called "tipping hypothesis" (Irvine et al. (2007)). Although tipping only benefits some investors, it is not prohibited by regulations in most countries as the Association for Investment Management and Research (AIMR) guidelines proscribe it. ${ }^{3}$ Some participants of financial markets recognize tipping as a common practice, which is described by brokerage firms as a reward for particular clients (i.e. institutional investors). Thus, policy makers in major countries tend to emphasize the need for stricter regulation about tipping, which is an unfair trading practice that goes against the interests of most investors.

A research department of a brokerage firm tends to recover some portion of the costs of research from commission revenues on the trading activity of institutional investors who benefit from the research. Yet, if the tipping practice is limited, brokerage firms would lose their commission revenues because institutional investors reduce the value of research. Then, brokerage firms cannot recover the cost of their research. For this reason, some research about tipping argues that brokerage firms have economic incentives to provide in advance the recommendation or recommendation changes of analysts' reports to selective investors [Irvine et al.(2007); Christophe et al. (2010)].

Irvine et al. (2007) examine the practices of brokerage firms which provide selective institutional investors with their affiliated analysts' initial buy recommendations before the public release. They document evidence on the existence, extent, and characteristics of tipping using a proprietary database of institutional trading activity around the release date of analysts' initial reports. ${ }^{4}$

\footnotetext{
${ }^{3}$ Refer to Irvine et al. (2007): 742.

${ }^{4}$ Irvine et al. 2007 used limited data from the consulting firm Plexus Group, which monitors the costs of institutional trading.
} 
According to their research results, institutional trading volume is abnormally high four days before the release of analysts' initial buy recommendations which contain their positive recommendations. Institutional buying is distinctive even after controlling for past returns. They argue that the results are not driven by momentum trading as reported by Griffin et al. (2003), but by tipping-induced trading. Christophe et al. (2010) also find that the institutional activities of short selling are higher in the three days before analysts publicly announce their recommendation downgrades. They argue that the results are more consistent with the tipping hypothesis than the prediction hypothesis which posits that short sellers successfully predict downgrades on the basis of public information about the firms' financial position. These studies suggest that institutional investors and short sellers receive tips prior to the release of reports. However, Blau and Wade (2012) test the tipping hypothesis using short selling data around both recommendation downgrades and upgrades, and find higher short selling prior to upgrades as well as downgrades. They contend that short selling prior to both downgrades and upgrades is likely to be more speculative in nature rather than informed.

Meanwhile, Green (2006) presumes that institutional investors pay significant amounts to obtain real-time access to the research of brokerage firms through information providers such as First Call, and then examines the short-term informational advantage of brokerage firms on analysts' recommendation changes. Green (2006) documents that market participants with early access to recommendation changes have profitable opportunities of investment and then get average re- turns of 1.02 percent $(1.50 \%)$ for two days following the pre-release of recommendation upgrades/downgrades by purchasing (selling short) quickly. Juergens and Lindsey (2009) also conjecture that even though the research departments of large brokerage firms are sources of information, these units do not generate income directly so they rely on financial support from other business departments of the firms. They examine the trading activities of Nasdaq market makers, who have affiliated analysts, around recommendation changes. They find that the trading volume of the market makers associated with recommendation changes by their affiliated analysts displays a disproportionate increase, and the selling volume increases in the two days preceding a downgrade.

\section{Data Description}

To investigate the informed trading before recommendation changes, we first obtain the data in analysts' reports on South Korean companies from a database, FnConsensus of FnGuide. ${ }^{5}$ The South Korean financial data provider, FnGuide, collects data on analysts' reports from 2000 onwards. Due to this time limitation, our sample includes analysts' recommendation data for the companies listed on the Korea Stock Exchange over the fiscal years of 2001-2008. We exclude financial companies following previous literature. We then combine accounting, trading volume by investor types, and stock return data with the analysts' forecast data. We obtain annual accounting data over the sample period of 2001-2008 from Total Solution 2000 (TS 2000), a database compiled

\footnotetext{
${ }^{5}$ We also collect analysts' forecast data from IBES. We find that the data from local data provider, FnGuide is more comprehensive than that from IBES, so we use the data from FnGuide.
} 
by the Korean Listed Companies' Association. We obtain the daily trading volume of each stock by domestic individuals, domestic institutions, and foreigners around the announcement dates of recommendation changes from Korea Exchange. We also obtain stock return data and Korean market index around the dates of recommendation changes from a database (KIS-value) of the Korean Information Service (KIS). The KIS is affiliated with Moody's and is a leading provider of creditrelated information and services in South Korea. Our sample consists of all stocks that satisfy the following criteria.

(a) There should be at least one analyst who issues a recommendation for the stock and changes the recommendation within 180 calendar days.

(b) At least two analysts, other than the revising analyst, should have active recommendations for the stock as of the day before the change. We consider a recommendation to be active for up to 180 days after it is issued. We impose the 180-day criterion to screen out stale recommendations.

(c) The stock price should be at least 1,000 Won (about 1 USD) on the day before the recommendation change date.

(d) The stock return data around the dates of recommendation changes should be available on KIS-value.

(e) The annual accounting data from Total Solution 2000 (TS 2000), a database compiled by the Korean Listed Companies' Association should be obtained.

(f) The daily trading volume of each stock by domestic individuals, domestic institutions, and foreigners around earnings announcement dates from Korea Exchange should be obtained. (g) We exclude firms with a combined ownership of institutions and foreigners of less than 5 percent since we are investigating whether institutional investors have better information.

We then classify recommendation changes as herding and non-herding, movement toward or away from the consensus following Jegadeesh and Kim (2010). The consensus is the average of active recommendations just before the recommendation changes. Analysts' recommendations rate stocks as "strong buy," "buy," "hold," "sell," and "strong sell." To calculate the consensus, we convert the recommendations to numerical scores where " 5 " is strong buy, " 4 " is buy, and so on. Therefore, we map an upgrade to a positive number and a downgrade to a negative number. For most of our analyses, we use only the non-herding sample which consists of 1,281 upgrades and 1,584 downgrades since the herding tends not to bring new information to capital markets (refer to Jegadeesh and Kim (2010)).

Panel A of Table 1 present the number of upgrades and downgrades year by year. Analysts tend to avoid issuing "sell" or "strong sell" recommendations. Out of 1,281 upgrades, 1,201 recommendations (93.8\%) are changes to "buy" from "hold," "sell," or "strong sell." Out of 1,584 downgrades, 1,485 recommendations (93.7\%) are changes to "hold" from "buy" or "strong buy." Most of the recommendation changes happened in the period of 2004-2006.

Panel B of Table 1 presents descriptive statistics of each variable to explain the characteristics of sample firm-years. The panel presents the mean, 75 percentile, median, 25 percentile, and standard deviation of each variable. The mean total assets is about 44,832 billion Won and the mean market capi- 
Parketal.

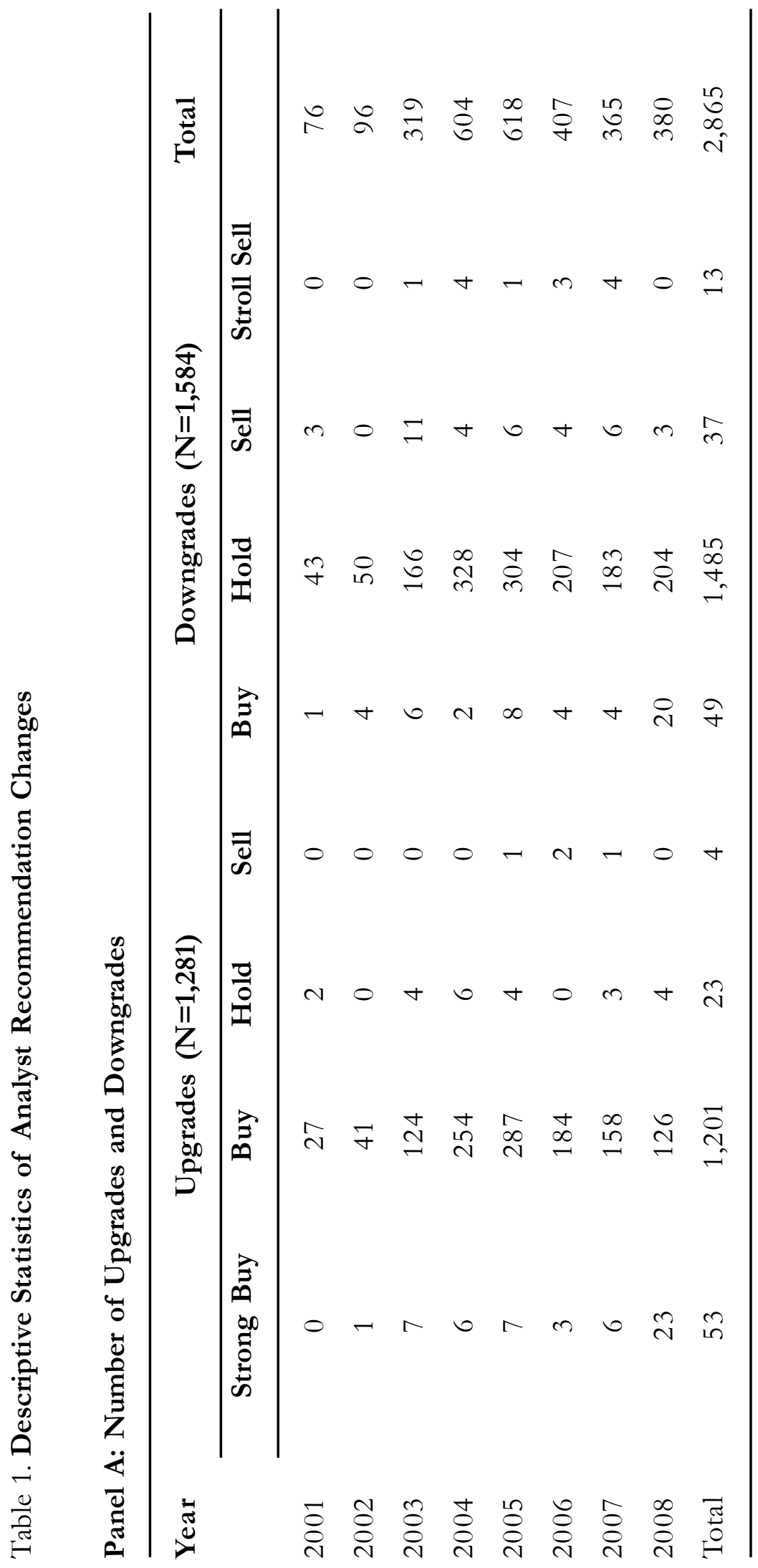


Gadjah Mada International Journal of Business -September-December, Vol. 16, No.3, 2014

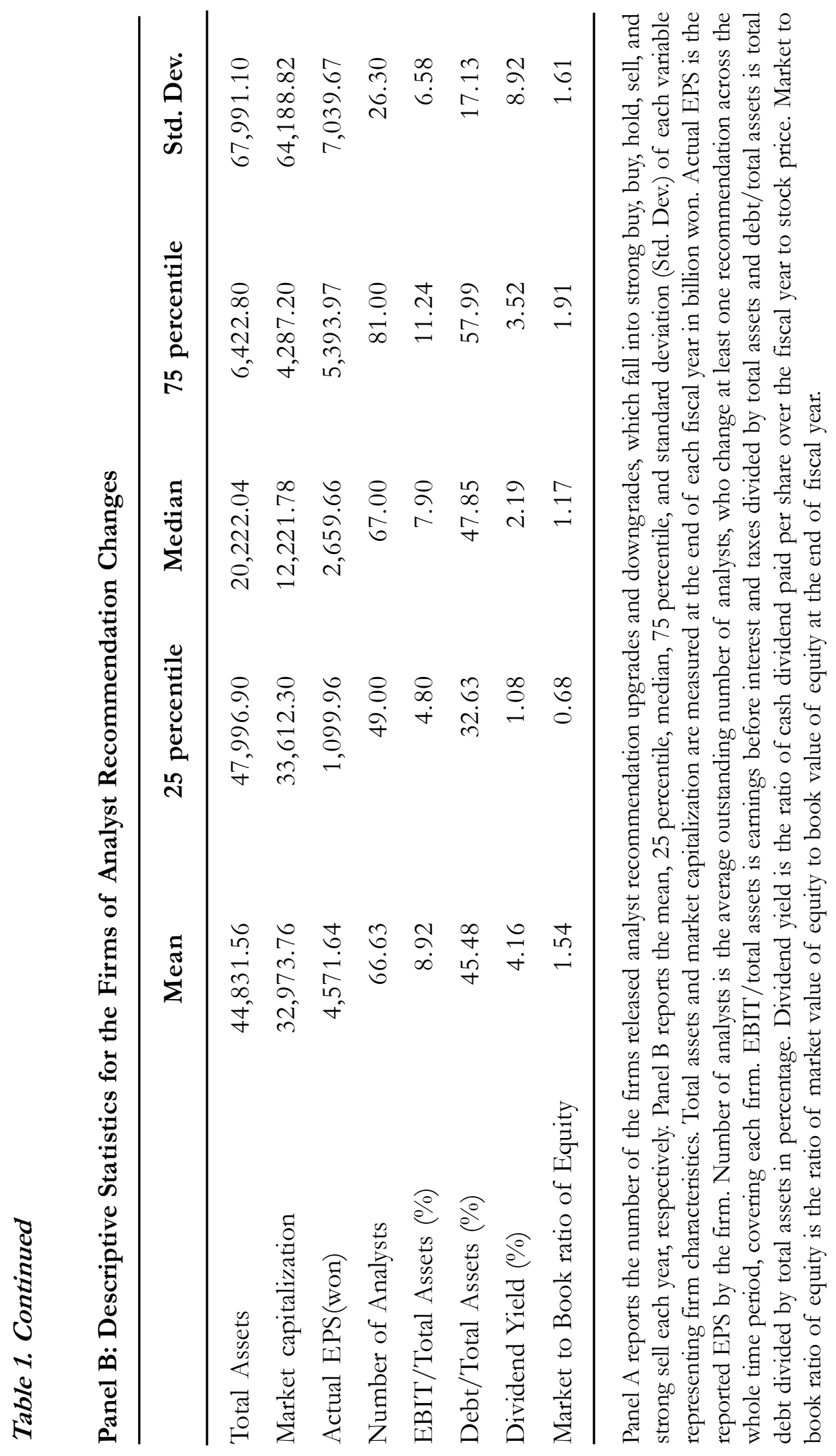


talization is about 32,974 billion won. ${ }^{6}$ The mean EPS (earnings per share) is about 4,572 Won and the mean number of analysts following is about 67 . The mean profitability (earnings before interest and taxes divided by total assets) is about 9 percent and the mean leverage (total debt divided by total assets) is 46 percent. The mean dividend yield (cash dividend paid per share divided by stock price) is about 3.8 percent and the mean market to book ratio of equity is about 1.54 .

\section{Empirical Findings}

Since the different characteristics of upgraded vs. downgraded firms can affect the results of our empirical tests, we first do difference tests in firm characteristics between the two sub-samples. In Table 2, we report the results of the mean and median difference tests in firm characteristics with recommendation upgrades vs. downgrades. Total assets and market capitalization are not statistically different between the two subsamples. Also, EPS and the number of analysts following are not statistically different between the two sub-samples. The mean (median) profitability (EBIT divided by total assets) is 8.70 percent $(7.75 \%)$ for upgraded firms while it is 9.10 percent $(8.00 \%)$ for downgraded firms. The mean difference is marginally significant, but the median difference is not significant. The leverage, dividend yield, and the market to book ratio of equity are not statistically different between the two sub-samples. These results suggest that the characteristics of upgraded and downgraded firms are not significantly different.

To verify whether analysts' recommendation changes bring new information to capi- tal markets, we examine stock price changes around the announcement dates of the recommendation changes. We measure the abnormal return (AR) and cumulative abnormal return (CAR) around the announcements of analysts' recommendation changes. $A R_{i, t}$ is a market-adjusted return for a firm $i$ on day $t$, calculated in the following way:

$$
\mathrm{AR}_{\mathrm{i}, \mathrm{t}}=\mathrm{R}_{\mathrm{i}, \mathrm{t}}-\mathrm{R}_{\mathrm{m}, \mathrm{c}}
$$

where $R_{i, t}$ is a return for a firm $i$ on day $t$ and $R_{m, t}$ is a value-weighted return of all stocks traded on Korean exchanges on day $t$. Then, we calculate a CAR over the period from day $t_{1}$ to $t_{2}$ in the following way.

$$
\operatorname{CAR}_{\left(\mathrm{t}_{1}, \mathrm{t}_{2}\right)}=\sum_{\mathrm{t}=\mathrm{t}_{1}}^{\mathrm{t}_{1}} \mathrm{ARt}
$$

Panel A of Table 3 presents the mean abnormal return (AR), t-statistics, and percentage of positive abnormal returns on each event date around the announcements of recommendation upgrades and downgrades. The abnormal returns are significantly positive over the days of -4 to +4 around upgrades. However, the abnormal returns do not show consistent patterns before downgrades, which suggests that capital markets do not anticipate negative news in general.

Panel B of Table 3 presents the mean cumulative abnormal return (CAR), t-statistics, and percentage of positive CARs over the several event periods around upgrades and downgrades. The mean CAR over the trading days from -5 to -1 before upgrades is 1.21 percent and significantly different from zero at 1 percent confidence level, which suggests that capital markets anticipate positive

\footnotetext{
${ }^{6}$ Won is a unit of Korean currency.
} 


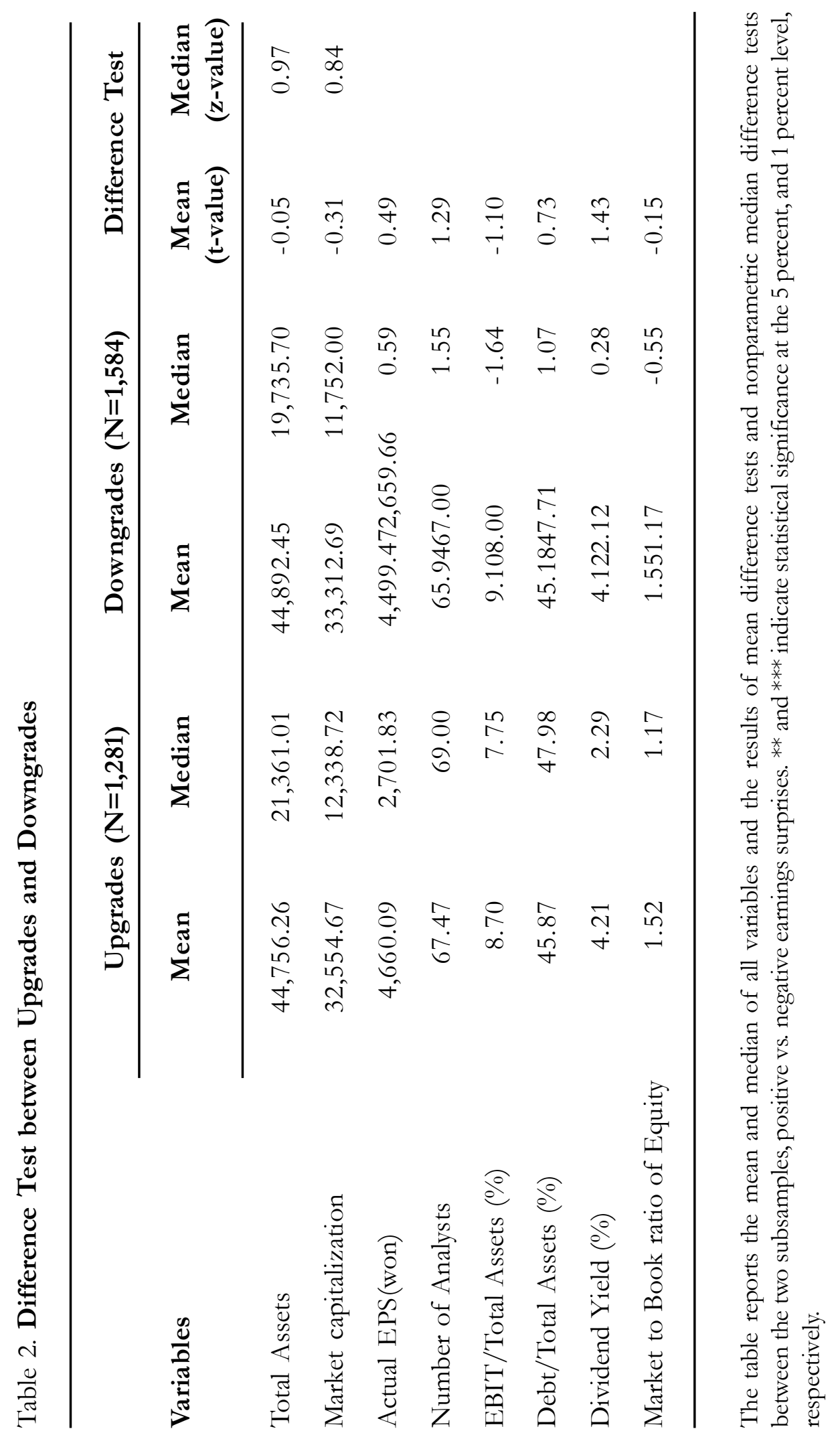


Parketal.

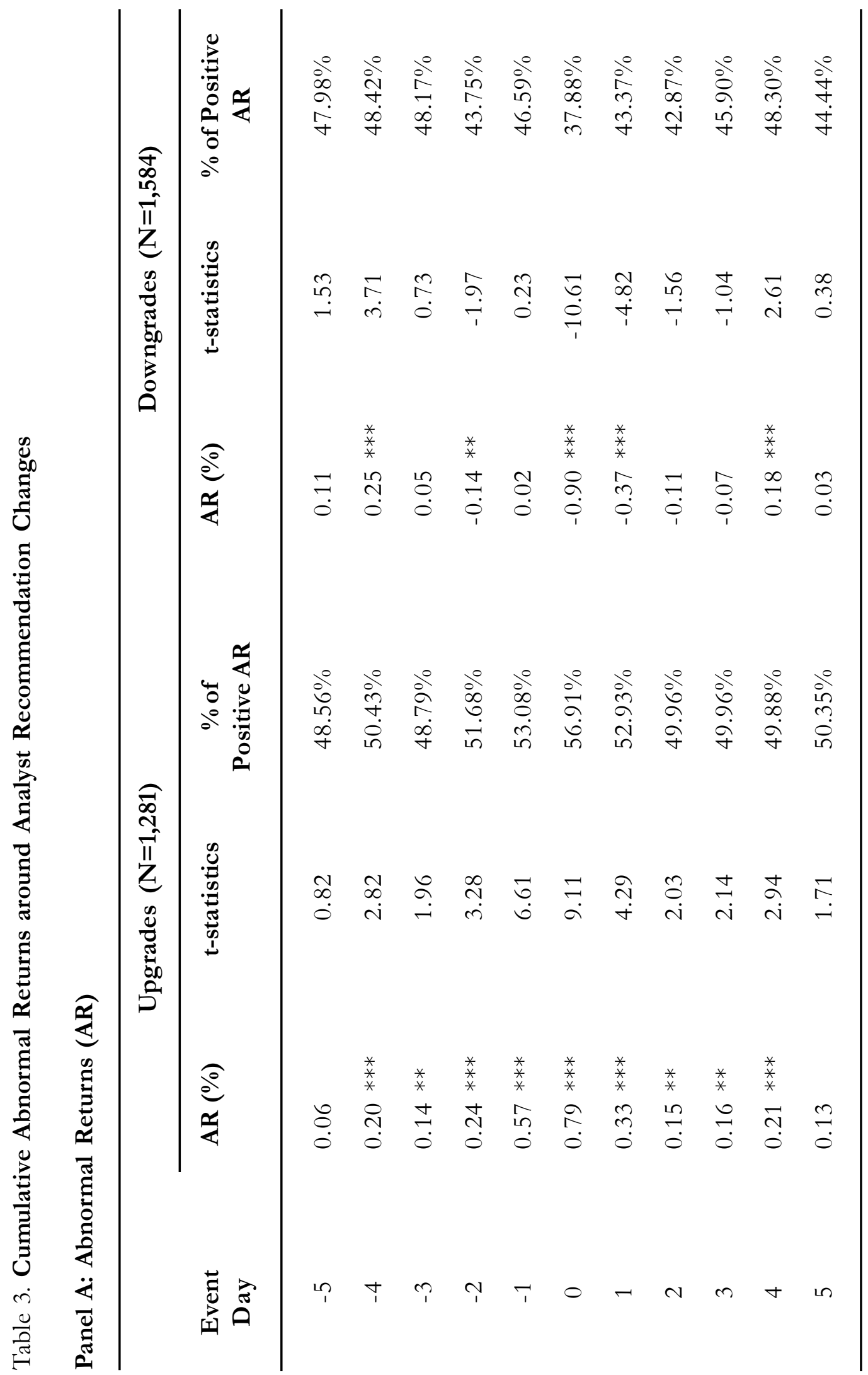


Gadjah Mada International Journal of Business - September-December, Vol. 16, No. 3, 2014

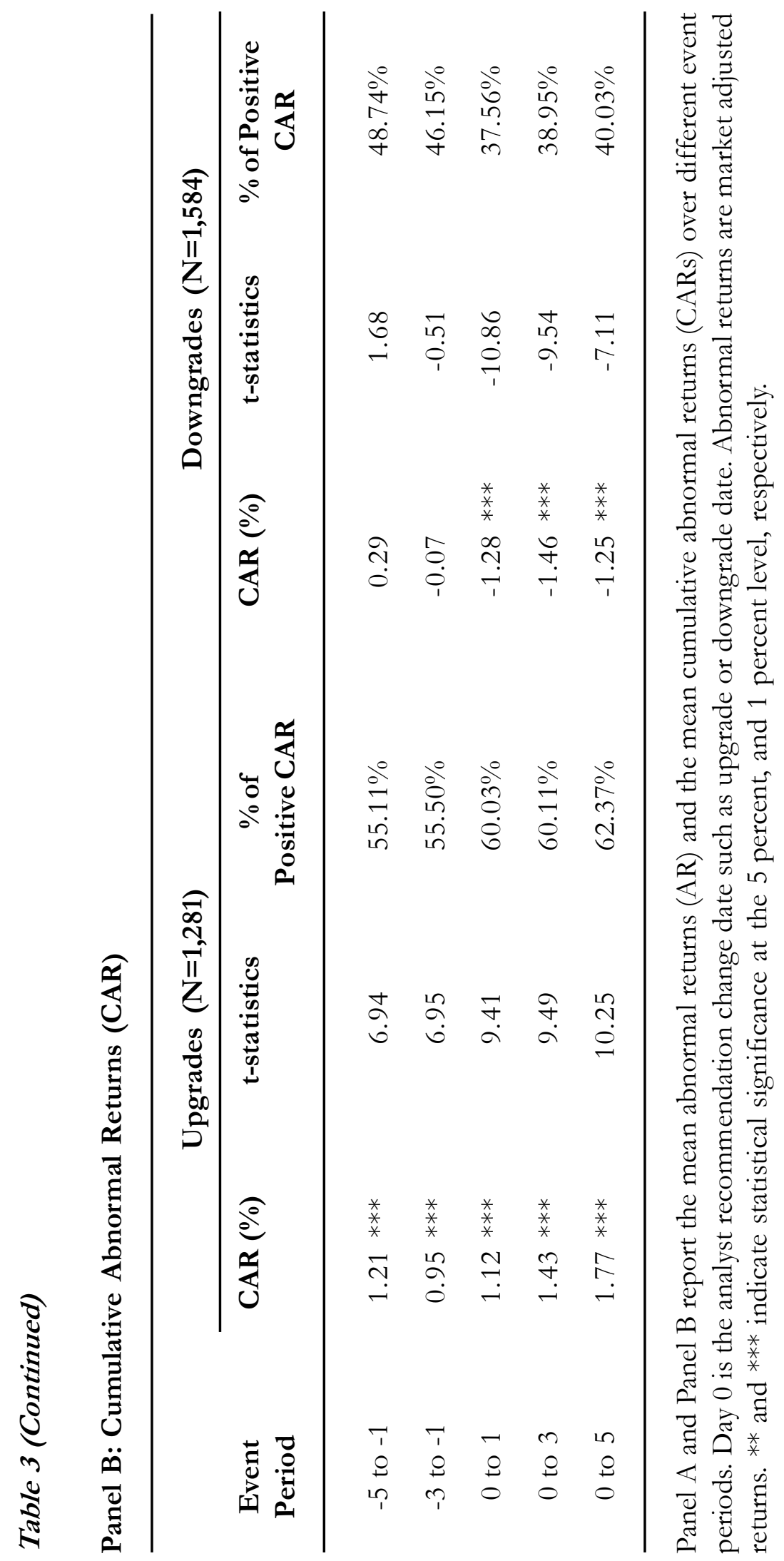


news or analysts slowly adjust to the performance of firms. The mean CAR is 1.77 percent over the days of 0 to 5 after the announcements of upgrades, which indicates that the stock prices continue to increase after the positive event. However, stock prices decline only after the announcements of recommendation downgrades, which indicates that investors do not anticipate recommendation downgrades in advance. Right after the announcement of recommendation downgrades, investors react significantly negatively to the recommendation downgrades issued by analysts. We find that the mean CAR $(-1.25 \%)$ over the period of days 0 to 5 is significant with the p-value of less than 0.01 . The results indicate that recommendation downgrades issued by analysts are more surprising to capital markets. In addition, the percentage of positive CARs is much higher on the recommendation upgrades than downgrades. The findings in Table 3 are consistent with the previous evidence that analysts' stock recommendations have at least a short-term investment value (see, e.g., Stickel (1995); Womack (1996); Barber et al. (2001); Jegadeesh et al. (2004); Green (2006)).

Our main interest is whether any type of investors anticipate the announcements of analysts' recommendation changes and take advantage of their superior information. If institutional investors have an informational advantage on the upcoming recommendation changes compared to individual and foreign investors, they would buy stocks before upgrades and sell stocks before downgrades. To test the hypothesis, we use a standardized trading imbalance (STI) to measure the direction of the trading by each type of investors before the recommendation changes following Malmendier and Shanthikumar (2007) and Lai and Teo (2008). We first calculate the trade imbalance (TI) of a firm $i$ by $x$ type investor on day $t$ as Equation 3.

$$
\mathrm{TI}_{\mathrm{i}, \mathrm{x}, \mathrm{t}}=\frac{\text { Buy Volume }_{\mathrm{i}, \mathrm{t}, \mathrm{S}}-\text { Sell Volume }_{\mathrm{i}, \mathrm{t}, \mathrm{t}}}{\text { Buy Volume }_{\mathrm{i}, \mathrm{x}, \mathrm{t}}+\text { Sell Volume }_{\mathrm{i}, \mathrm{t}}}
$$

We then normalize TI to get the standardized trade imbalance (STI) using the standard deviation of the TI over the year as Equation 4.

$$
\operatorname{STI} I_{i, x, t}=\frac{T I_{i, x, t}-T_{i, x, y e a r ~(t)}}{\operatorname{std}\left(\mathrm{TI}_{i, x, y e a r}(t)\right.}
$$

If STI is positive (negative), a specific type of investors buy/sell the stock.

Panel A of Table 4 shows the mean cumulative STI by individuals, institutions, and foreigners around the announcements of recommendation upgrades. To investigate which investors have an informational advantage over the short-term period, we measure the STIs by each investor group around the event periods of days from -5 to -1 , from -3 to -1 , from 0 to 1 , from 0 to 3 , or from 0 to 5 . Over the period from day -5 to day -1 , the mean STI by individuals is about -0.13 , the mean STI by institutions is about 0.36 , and that by foreigners is -0.10 . The STIs by individuals and foreigners are not statistically different from zero, but the STI by institutions is statistically different from zero at the confidence level of 1 percent. The result indicates that institutions tend to buy the stocks before upgrades, whereas individuals and foreigners do not anticipate the good news. Over the period from day 0 to day 1 (or from day 0 to day 3 , or day 0 to day 5 ), the STI by individuals is negative and that by institutions is positive. The result indicates that the institutions continue to buy the stocks even after the announcements of recommendation up- 
grades. This also suggests that the directional trading of stocks around recommendation upgrades tend to be initiated by institutional investors. However, the STIs by foreign investors are not different from zero around the recommendation upgrades, which indicates that the foreign investors do not trade differently around the events. The ANOVA test also shows that each STI is different from those by other investor types.
Panel B of Table 4 presents the mean cumulative STI by each investor type around the announcements of recommendation downgrades. The STI by institutions over the period of days from -5 to -1 is about -0.28 with $\mathrm{p}$-value of less than 0.01 , which means that domestic institutions sell the stocks anticipating the recommendation downgrades. However, the STIs by individuals and foreigners are not statistically different from

Table 4. Standardized Trade Imbalance (STI) around Analyst Recommendation Changes

Panel A: Recommendation Upgrades

\begin{tabular}{lccccc}
\hline Investor Type & $\mathbf{- 5}$ to $\mathbf{- 1}$ & $\mathbf{- 3}$ to $\mathbf{- 1}$ & $\mathbf{0}$ to $\mathbf{1}$ & $\mathbf{0}$ to $\mathbf{3}$ & $\mathbf{0}$ to $\mathbf{5}$ \\
\hline Individual Investor & -0.13 & -0.10 & $-0.16^{* * *}$ & $-0.40^{* * *}$ & $-0.62^{* * *}$ \\
& $(-1.51)$ & $(-1.68)$ & $(-3.74)$ & $(-5.64)$ & $(-6.52)$ \\
Institution Investor & $0.36^{* * *}$ & $0.29^{* * *}$ & $0.31^{* * *}$ & $0.54^{* * *}$ & $0.66^{* * *}$ \\
& $(4.34)$ & $(4.81)$ & $(7.02)$ & $(7.61)$ & $(6.94)$ \\
Foreigner Investor0 & -0.10 & -0.11 & -0.04 & -0.02 & 0.04 \\
& $(-1.14)$ & $(-1.87)$ & $(-0.96)$ & $(-0.22)$ & $(0.42)$ \\
\hline
\end{tabular}

Panel B: Recommendation Downgrades

\begin{tabular}{lccccc}
\hline Investor Type & $\mathbf{- 5}$ to $\mathbf{- 1}$ & $\mathbf{- 3}$ to $\mathbf{- 1}$ & $\mathbf{0}$ to $\mathbf{1}$ & $\mathbf{0}$ to $\mathbf{3}$ & $\mathbf{0}$ to $\mathbf{5}$ \\
\hline Individual Investor & 0.06 & 0.08 & $0.17^{* * *}$ & $0.29 * * *$ & $0.38^{* * *}$ \\
& $(0.83)$ & $(1.52)$ & $(4.21)$ & $(4.51)$ & $(4.44)$ \\
Institution Investor & $-0.28^{* * *}$ & $-0.20^{* * *}$ & $-0.21^{* * *}$ & $-0.34 * * *$ & $-0.46^{* * *}$ \\
& $(-3.73)$ & $(-3.71)$ & $(-5.05)$ & $(-5.22)$ & $(-5.26)$ \\
Foreigner Investor & 0.07 & 0.06 & 0.03 & -0.02 & -0.08 \\
& $(1.00)$ & $(1.18)$ & $(0.68)$ & $(-0.25)$ & $(-0.95)$ \\
\hline
\end{tabular}

Panel A and B report cumulative standardized trade imbalance (STI) by three investor types, individuals, institutions, and foreigners over different event periods for the firms released analyst recommendation changes. Panel B reports the coefficient estimates on the upgrade and downgrade dummies when standardized trade imbalance is regressed on the upgrade and downgrade dummies. Day 0 is the analyst recommendation change date. If STI is positive (negative), buying volume is larger (smaller) than selling volume. ${ }^{* *}$ and ${ }^{* * *}$ indicate statistical significance at the 5 percent, and 1 percent level, respectively. 
zero. The results also show that the domestic institutions continue to sell the stocks after the event, which indicates that the trading around recommendation downgrades is initiated by the domestic institutional investors. The ANOVA test shows that each STI is statistically different from those by other investor types. The results in Table 4 suggest that institutional investors trade stocks anticipating the direction of recommendation changes.

To corroborate whether domestic institutions successfully exploit their informational advantage around recommendation changes, we investigate whether their trading before the events predicts the abnormal return upon the announcements of the events in multivariate regressions. We mainly estimate the Equation 5.

$$
\begin{aligned}
\operatorname{CAR}_{[0,5]}= & \beta_{0}+\beta_{1} \mathrm{STI}_{[-5,-1]}+\beta_{2} \mathrm{CAR}_{[-25,-1]}+ \\
& \beta_{3} \mathrm{CAR}_{[-5,-1]}+\beta_{4} \text { Size }+\beta_{5} \mathrm{MB}+ \\
& \beta_{6} \text { NumAnal }+\varepsilon_{\mathrm{i}, \mathrm{t}} \ldots \ldots \ldots \ldots .(5)
\end{aligned}
$$

We try to find the relation between cumulative abnormal return (CAR) over the period of days from 0 to 5 and the STI for each investor type over the period of days from -5 to -1 in the regression. We include the CARs over the period of days from -25 to -1 to control for stock return momentum and over the period of days from -5 to -1 to control for return reversal. We also include firm size, market to book ratio of equity $(\mathrm{MB})$, and the number of analysts covering each firm-year (NumAnal) to control for information asymmetry. The firm size is calculated as a natural log of market capitalization at the end of the fiscal year.

Since our sample of firms with recommendation upgrades and downgrades is a cross-sectional time-series (panel) data, we estimate the equation using OLS with clustered standard errors and report the results in Table 5. ${ }^{7}$ The dependent variable is the CAR over the days from 0 to 5 in all the models. As main explanatory variables, we use the STI for institutions over the days from -5 to -1 in model 1 and the STIs for individuals and foreigners in models 2 and 3. Model 4 includes the STIs for three investor types as explanatory variables. The coefficient on the STI for institutions is 0.15 and statistically significant with a p-value of less than 0.01 in model 1 , which indicates that the institutional investors' buying or selling volume before upgrades and downgrades is positively associated with the stock returns after the announcements of the recommendation changes. However, the STI for individuals are not related to the abnormal returns in model 2 , which suggests that individual investors do not trade the stock anticipating the recommendation changes. The coefficient on the STI for foreigners is negative but insignificant in model 3 , which means that foreign investors do not trade the stock anticipating the event. The coefficients on CARs over the days from -5 to -1 are significantly negative in all models, which indicate that stock returns show shortterm reversal patterns around recommendation changes. The coefficients on the variables representing information asymmetry are all insignificant or marginally significant.

In untabulated tests, we divide the sample into firms with upgrades and firms with downgrades and run the same regressions as reported in Table V. The results are qualitatively similar to those in Table V. The coefficients on institutions' STIs are significantly positive in upgrade and downgrade samples, which means that the institutional

\footnotetext{
${ }^{7}$ Refer to Pertersen (2009) about the OLS with clustered standard errors.
} 
Table 5. The Regression on Cumulative Abnormal Returns (CARs)

\begin{tabular}{|c|c|c|c|c|}
\hline & \multicolumn{4}{|c|}{ Dependent Variable CAR[0,5] } \\
\hline & Model 1 & Model 2 & Model 3 & Model 4 \\
\hline Individuals STI $[-5,-1]$ & $\begin{array}{c}0.15^{* * *} \\
(2.99)\end{array}$ & & & $\begin{array}{c}0.21 * * * \\
(3.12)\end{array}$ \\
\hline Institutions STI $[-5,-1]$ & & $\begin{array}{c}0.02 \\
(0.29)\end{array}$ & & $\begin{array}{c}0.11 \\
(1.50)\end{array}$ \\
\hline Foreigners STI[-5,-1] & & & $\begin{array}{l}-0.07 \\
(-1.38)\end{array}$ & $\begin{array}{c}0.05 \\
(0.83)\end{array}$ \\
\hline CAR $[-5,-1]$ & $\begin{array}{c}-0.12^{* * *} \\
(-3.81)\end{array}$ & $\begin{array}{c}-0.10^{* * *} \\
(-2.75)\end{array}$ & $\begin{array}{c}-0.11 * * * \\
(-3.07)\end{array}$ & $\begin{array}{c}-0.11 * * * \\
(-2.88)\end{array}$ \\
\hline CAR $[-25,-1]$ & $\begin{array}{l}-0.01 \\
(-0.68)\end{array}$ & $\begin{array}{l}-0.01 \\
(-0.69)\end{array}$ & $\begin{array}{l}-0.01 \\
(-0.83)\end{array}$ & $\begin{array}{l}-0.01 \\
(-0.84)\end{array}$ \\
\hline Firm Size & $\begin{array}{c}0.04 \\
(0.24)\end{array}$ & $\begin{array}{c}0.03 \\
(0.15)\end{array}$ & $\begin{array}{c}0.02 \\
(0.12)\end{array}$ & $\begin{array}{c}0.03 \\
(0.16)\end{array}$ \\
\hline Market to Book ratio of Equity & $\begin{array}{l}-0.17 \\
(-1.67)\end{array}$ & $\begin{array}{l}-0.17 \\
(-1.74)\end{array}$ & $\begin{array}{l}-0.17 \\
(-1.71)\end{array}$ & $\begin{array}{l}-0.16 \\
(-1.59)\end{array}$ \\
\hline Number of Analysts following & $\begin{array}{l}-0.01 \\
(-0.95)\end{array}$ & $\begin{array}{c}-0.01 \\
(-0.84)\end{array}$ & $\begin{array}{l}-0.01 \\
(-0.87)\end{array}$ & $\begin{array}{l}-0.01 \\
(-0.95)\end{array}$ \\
\hline Intercept & $\begin{array}{c}0.63 \\
(0.58)\end{array}$ & $\begin{array}{c}0.24 \\
(0.06)\end{array}$ & $\begin{array}{c}0.78 \\
(0.70)\end{array}$ & $\begin{array}{c}0.75 \\
(0.68)\end{array}$ \\
\hline Adj. $R^{2}(\%)$ & 1.73 & 1.32 & 1.50 & 1.94 \\
\hline
\end{tabular}

The table reports the results of clustered OLS on cumulative abnormal returns (CAR) over the period of days, 0 to 5. Model 1-3 are the result for the firms released analyst recommendation changes. Institutions, individuals, or foreigners STI $[-5,-1]$ mean cumulative standardized trade imbalance by each investor type over the period of -5 to -1 . CAR[-50,-26] mean CAR over pre-release days from -50 to -26 . CAR[-5,-1] mean CAR over pre-release days from -5 to -1 . Firm size is a natural log of market capitalization measured at the end of fiscal year. Market to book ratio of equity is the ratio of market value of equity to book value of equity at the end of fiscal year. Number of analysts is the average outstanding number of analysts, who change at least one recommendation across the whole time period, covering each firm. T-statistics are in parenthesis. ${ }^{* *}$ and ${ }^{* * *}$ indicate statistical significance at the 5 percent and 1 percent level, respectively.

investors buy/sell stocks before recommendation upgrades/downgrades. However, the coefficients on STIs by individuals and foreigners are insignificant.

Overall, the results in Table 5 suggest that institutional investors trade stocks an- ticipating the direction of recommendation changes during days from -5 to -1 prior to the announcements of the changes. This evidence corroborates the univariate results found in Table 5. 


\section{Conclusion}

We investigate whether there exists information asymmetry among investors around recommendation changes issued by sell-side analysts and whether any specific type of investors make use of the superior information. Korean data is ideal for this research since the Korea Exchange provide the daily buying and selling volume by individuals, institutions, and foreigners.
We document that institutions buy/sell the stock before recommendation upgrades/ downgrades are issued by analysts. The result is consistent with our conjecture that institutional investors are better informed than individuals on upcoming recommendation changes. Foreign investors do not make any directional trades around the event, which is consistent with the argument that they tend not to trade using the information on upcoming corporate events in emerging markets.

\section{References}

Agrawal, A., and M. A. Chen. 2008. Do analyst conflicts matter? Evidence from stock recommendations. Journal of Law and Economics 51: 503-537.

Asquith, P., M. Mikhail, and A. Au. 2005. Information content of equity analyst reports. Journal of Financial Economics 75: 245-82.

Barber, B., R. Lehavy, M. McNichols, and B. Trueman. 2001. Can investors profit from the prophets?, Security Analyst Recommendations and Stock Returns. Journal of Finance 56: 531-563.

Blau, B. M., and C. Wade. 2012. Informed or speculative: Short selling analyst recommendations. Journal of Banking and Finance 36: 14-25.

Boni, L., and K. Womack. 2006. Analysts, industries, and price momentum. Journal of Financial and Quantitative Analysis 41: 85-109.

Brennan, M. J., and H. H. Cao. 1997. International portfolio investment flows. Journal of Finance 52: 18511880.

Brown, N. C., K. D. Wei, and R. Wermers. 2009. Analyst recommendations, mutual fund herding, and overreaction in stock prices. Working Paper.

Chen, X., and Q. Cheng. 2006. Institutional holdings and analysts' stock recommendations. Journal of Accounting, Auditing and Finance 21: 399-440.

Choe, H., B-C. Kho, and R. M. Stulz. 2005. Do domestic investors have an edge? The trading experience of foreign investors in Korea. Review of Financial Studies 18: 795-829.

Christophe, S. E., M. G. Ferri, and J. Hsieh. 2010. Informed trading before analyst downgrades: Evidence from short sellers. Journal of Financial Economics 95: 85-106.

Cowen, A., B. Groysberg, and P. Healy. 2006. Which types of analyst firms are more optimistic? Journal of Accounting and Economics 41: 119-146.

Dugar, A., and S. Nathan. 1995. The effect of investment banking relationships on financial analysts' earnings forecasts and investment recommendations. Contemporary Accounting Researcb 12: 131-160.

Francis, J., and L. Soffer. 1997. The relative informativeness of analysts' stock recommendations and earnings forecast revisions. Journal of Accounting Research 35: 193-211. 
Green, T. C. 2006. The value of client access to analyst recommendations. Journal of Financial and Quantitative Analysis 41: 1-24.

Griffin, J. M., J. H. Harris, and S. Topaloglu. 2003. The dynamics of institutional and individual trading. Journal of Finance 58: 2285-2320.

Grinblatt, M., and M. Keloharju. 2000. The investment behavior and performance of various investor types: A study of Finland's unique data set. Journal of Financial Economics 55: 43-67.

Irvine, P., M. Lipson, and A. Puckett. 2007. Tipping. Review of Financial Studies 20: 741-768.

Ivkovic, Z., and N. Jegadeesh. 2004. The timing and value of forecast and recommendation revisions. Journal of Financial Economics 73: 433-463.

Jegadeesh, N., J. Kim, S. Krische, and C. Lee. 2004. Analyzing the analysts: When do recommendations add value? Journal of Finance 59: 1083-1124.

Jegadeesh, N., and W. Kim. 2010. Do analysts herd? An analysis of recommendations and market reactions. Review of Financial Studies 23: 901-937.

Juergens, J. L., and L. Lindsey. 2009. Getting out early: An analysis of market making activity at the recommending analyst' firm. Journal of Finance 64: 2327-2359.

Lai, S., and M. Teo, 2008. Home-biased analysts in emerging markets. Journal of Financial and Quantitative Analysis 2008: 685-716.

Malmendier, U., and D. Shanthikumar. 2007. Are small investors naïve about incentives? Journal of Financial Economics 85: 457-489.

Mehran, H., and R. Stulz. 2007. The economics of conflicts of interest in financial institutions. Journal of Financial Economics 85: 267-296.

Mikhail, M. B., B. R. Walther, and R. H. Willis. 2007. When security analysts talk, who listens? Accounting Review 82: 1227-1253.

Michaely, R., and K. L. Womack. 1999. Conflict of interest and the credibility of underwriter analyst recommendations. The Review of Financial Studies 12: 653-686.

Petersen, M. A. 2009. Estimating standard errors in finance panel data sets: Comparing approaches. Review of Financial Studies 22: 435-480.

Stickel, S., 1995. The anatomy of the performance of buy and sell recommendations. Financial Analyst Journal 51: 25-39.

Womack, K. 1996. Do brokerage analyst recommendations have investment value? Journal of Finance 51: 137-167. 
